\title{
MENINGKATKAN KETERAMPILAN ARGUMENTASI KRITIS DAN SELF EFFICACY SISWA DENGAN MODEL INQUIRY BASED LEARNING PADA MATERI LARUTAN PENYANGGA
}

\section{Improving Critical Argumentation Skills And Self Efficacy Of Students With Inquiry Based Learning Models In Materials Of Buffer Solution}

\section{Siti Mariam*, Rusmansyah, Maya Istyadji}

Program Studi Pendidikan Kimia FKIP Universitas Lambung Mangkurat, Jl. Brigjend. H. Hasan Basry Banjarmasin 70123 Kalimantan Selatan Indonesia *email: sitimariam.1409@gmail.com

\begin{abstract}
Abstrak.Telah dilakukan penelitian tentang meningkatkan keterampilan argumentasi kritis dan self-efficacy siswa melalui model pembelajaran Inquiry Based Learning (IBL) pada materi larutan penyangga pada siswa kelas XI MIA 1. Penelitian ini bertujuan untuk mengetahui: (1) aktivitas guru; (2) aktivitas siswa; (3) self-efficacy siswa; (4) keterampilan argumentasi kritis siswa; (5) hasil belajar siswa. Metode dalam penelitian ini menggunakan rancangan penelitian tindakan kelas (PTK) dengan 2 siklus. Subjek penelitian adalah siswa kelas XI MIA 1 SMAN 9 Banjarmasin dengan jumlah 34 orang. Instrumen penelitian berupa tes dan non tes. Hasil penelitian menunjukkan peningkatan pada; (1) aktivitas guru menunjukkan kategori baik menjadi sangat baik, (2) aktivitas siswa menunjukkan kategori cukup aktif menjadi sangat aktif, (3) selfefficacy siswa menunjukkan kategori cukup baik menjadi baik, (4) keterampilan argumentasi kritis menunjukkan kategori cukup kritis menjadi kritis;(5) hasil belajar pengetahuan menunjukkan kategori sedang menjadi baik dengan model IBL.
\end{abstract}

Kata kunci: self-efficacy, keterampilan argumentasi kritis, inquiry based learning (IBL), larutan penyangga.

\begin{abstract}
Research has been conducted on improving students' critical argumentation and self-efficacy skills through the Inquiry Based Learning (IBL) learning model on buffer solution material in class XI MIA 1. This research aims to find out: (1) teacher activity; (2) student activities; (3) student self-efficacy; (4) students' critical argumentation skills; (5) student learning outcomes. The method in this study uses a class action research design (CAR) with 2 cycles. The subject of the research was the students of class XI MIA 1 SMAN 9 Banjarmasin with a total of 34 people. Research instruments in the form of tests and non-tests. The results showed an increase in; (1) teacher activity shows good to very good categories, (2) student activities show quite active to very active categories, (3) student self-efficacy shows good enough to be good categories, (4) critical argumentation skills show quite critical categories to be critical, (5) knowledge learning results indicate the category is being good with the IBL model
\end{abstract}

Keyword: self-efficacy, critical argumentation skills, inquiry based learning (IBL), buffer solution.

\section{PENDAHULUAN}

Pembelajaran K-13 mengharuskan siswa memiliki keterampilan 4C yaitu collaboration, comunication, critical thinking dan creativity. Pembelajaran K-13 membuat siswa memiliki keterampilan argumentasi kritis. Menurut Filsaime (2008)

Copyright @ JCAE-Jurnal Tugas Akhir Mahasiswa, e-ISSN 2613-9782

Program Studi Pendidikan Kimia FKIP Universitas Lambung Mangkurat 
siswa akan mempunyai keterampilan argumentasi kritis dan self-efficacy tinggi.

Studi pendahuluan melalui observasi siswa kelas XI MIA di SMAN 9 Banjarmasin, dengan memberikan soal larutan penyangga dan pertanyaan kepada siswa. siswa diberikan pertanyaan apakah mampu menyelesaikan dan bagaimana cara penyelesaiannya dari ragam soal tersebut. Siswa kesulitan dan merasa tidak yakin dengan jawabannya. Hal ini diperkuat dengan hasil tes awal tentang keterampilan argumentasi kritis dari Ennis yaitu merumuskan masalah, membuat rencana, menganalisis data dan membuat kesimpulan. Hasil tesnya hanya4 orang siswa yang tergolong kritis, 4 orang tergolong dalam cukup kritis dan 26 orang tergolong dalam kurang kritis.

Siswa yang dapat menjawab dengan benar merasa tidak yakin dengan jawabannya. Hal ini juga diperkuat dengan hasil tes awal self-efficacy dari Hanifah \& Agustini (2012). Hasil tesnya hanya4 orang siswa tergolong dalam sangat baik, 6 orang tergolong dalam baik, 19 orang tergolong dalam cukup baik, dan 5 orang tergolong dalam kurang baik. Sehingga mereka kurang percayadiri dalam bertanya, menjawab, memberikan argumen yang membuat ketidakyakinan terhadap jawaban.

Menurut Hamalik (2013) self-efficacy siswa meningkat dengan cara diberikan pertanyaan, dukungan dan ajakan untuk mencari sendiri pengetahuan, diiiringi meningkatnya keterampilan argumentasi kritis dan hasil belajar. Sehingga digunakan model pembelajaran berpusat pada siswa. Sejalan dengan pernyataan Hosnan (2014) pembelajaran yang berpusat pada siswa disetiap rangkaian kegiatan pembelajaran menekankan proses argumentasi kritis, logis dan analitis salah satunya adalah model pembelajar inquiry based learning (IBL). Hal ini juga sejalan dengan pendapat Mulyasa (2015) model IBL mampu meningkatkan keterampilan argumentasi kritis dan self-efficacy siswa. Bruner juga mengatakan proses belajar akan berjalan dengan baik dan kritis apabila siswa menemukan sendiri konsep, teori dan pemahaman melalui contoh-contoh yang berkaitan dengan kehidupan sehari-hari (Danim \& Khairil, 2011).

\section{METODE PENELITIAN}

Penelitian ini menggunakan jenis Penelitian Tindakan Kelas (PTK) model John Elliot. Menurut John Elliot penelitian tindakan dapat dikatakan sebagai penelitian terhadap situasi sosial untuk meningkatkan kualitas tindakan didalamnya. Adapun tahapannya mulai dari perencanaan, tindakan, observasi dan refleksi berfungsi memecahkan dan meningkatkan kualitas pembelajaran (Hopkins, 2011).

Penelitian ini berlangsung dari 16 April sampai 9 Mei 2019 dengan dilakukan 34 orang siswa kelas XI MIA 1 SMAN 9 Banjarmasin yang beralamat di jalan Tatah Makmur No.1 RT.32, Handil Bujur, Aluh-aluh, Banjar, Kalimantan Selatan 70247. Objek penelitian ini meliputi aktifitas siswa, keterlaksanaan aktifitas guru, keterampilan argumentasi kritis, self-efficay dan hasil belajar.

Data keterampilan argumentasi kritis dan hasil belajar pengetauan siswa diperoleh melalui teknik tes soal uraian. Soal tes keterampilan argumentasi kritis sebanyak 6 butir dan 5 butir soal pengetahuan serta data angket self-efficacy diperoleh melalui teknik tes pernyataan sebanyak 15 butir pernyataan disetiap akhir siklus. Data aktifitas siswa, keterlaksanaan aktifitas guru, hasil belajar sikap dan keterampilan siswa diperoleh melalui teknik nontes melalui lembar observasi.

\section{HASIL PENELITIAN DAN PEMBAHASAN Keterlaksanaan aktivitas guru}

Hasil observasi keterlaksanaan aktivitas guru dengan model IBL mengalami peningkatan dari kategori baik siklus I menjadi sangat baik siklus II. 


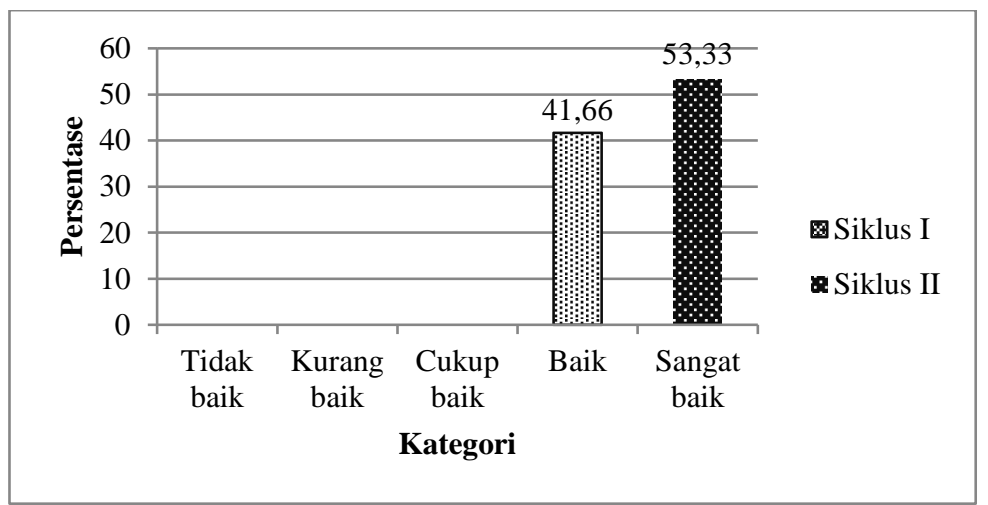

Gambar 1. Hasil observasi keterlaksanaan aktivitas guru

Siklus I sebagian siswa terlihat bingung dikarenakan belum terbiasa dengan model IBL, sehingga menyebabkan proses pembelajaran menjadi kurang maksimal dan belum menunjukkan peningkatan sesuai harapan. Siklus II guru melakukan perbaikan tindakan sebelumnya, seperti membimbing dan mengarahkan siswa disetiap kegiatan pembelajaran untuk menyelesaikan praktikum sesuai panduan yang ada di LKPD, guru berkeliling untuk memeriksa proses berlangsungnya pratikum agar tidak ada siswaa yang ribut, tidak fokus dan tidak ikut berpartisipasi menyelesaikan praktikum sehingga kegiatan pembelajaran menjadi lebih kondusif.

Menurut teori Bruner proses belajar dan mengajar akan berjalan baik apabila adanya umpan balik secara terus menerus. Sejalan dengan pendapat Sudjana (2014) bahwa terwujudnyaa pembelajaran yang berkualitas dilihat dari kemampuan guru dalam mengorganisir kelas dan perilaku siswa seperti memahami, mengikuti petunjuk dan semua peserta didik turut serta mengikuti kegiatan belajar mengajar. Sejalan oleh Hanifah \& Suhana (2012), guru sangat berperan penting dalam proses pembelajaran agar terdorong kooperatif dan kompetitif dikalangan siswa secara aktif, kreatif, inovatif dan menyenangkan.

\section{Aktivitas siswa}

Keterlaksanaana aktivitas siswa tidak terlepaas dari pengaruh guru. Hal ini menunjukkan bahwa keduanya saling memberikan pengaruh dan berkaitan (Kunandar, 2012). Hasil observasi aktivitas siswa mengalami peningkatan dari siklus I berada dikategori cukup aktif menjadi kategori sangat aktif pada siklus II. Pada siklus I siswa mengalami kendala ketika proses pembelajaran masih terlihat pasif karena belum memahami soal yang ada pada LKPD dan kurang terampil dalam berpendapat sehingga mereka perlu bimbingan guru. Trianto (2011) bependapat penyebab ssiwa mengalami kesulitan dalam pembelajaran dikarenakan belum terbiasa dengan model pembelajaran baru sehingga aktivitas siswa kurang maksimal.

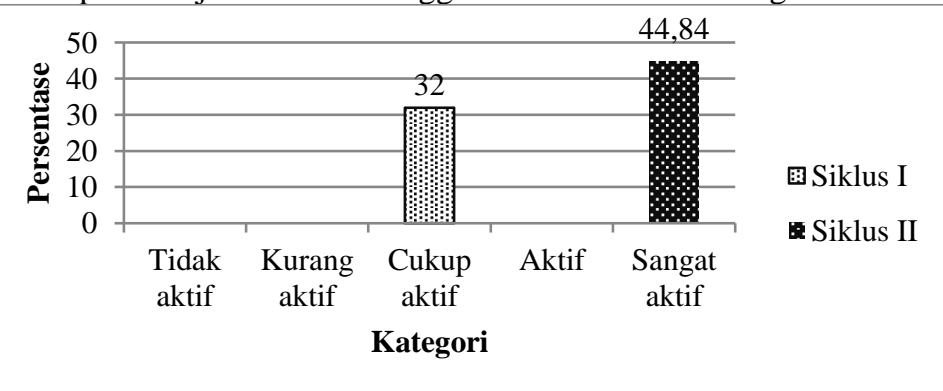

Gambar 2. Hasil observasi aktivitas siswa 
Siklus II terjadi peningkatan dikarenakan guru melakukan tindakan perbaikan caraa mengajar dengan cara membimbing siswa mulai dari tahap melakukan observasi menemukan masalah, merumuskan masalah, merumuskan hipotesis, menguji hipotesis sampai menarik kesimpulan sehingga siswa terbiasa dengan model IBL. Menurut Praseyowati \& Suyatno (2016) keberhasilan aktivitas siswa dalam memecahkan masalah secara kritis selama kegiatan pembelajaran dipengaruhi oleh aktivitas pengajar. Sejalan dengan pendapat Ariani, Hamid \& Leny (2015) siswa menjadi lebih aktif jika mulai terbiasa dengan model pembelajaran.

\section{Hasil belajar ranah sikap}

Penilaian aspek sikap mencakup rasa ingin tahu, kerjasamaa dan teliti. Hasil persentase observasi sikap siswa mengalami peningkatan dari kategori cukup baik menjadi kategori sangat baik.

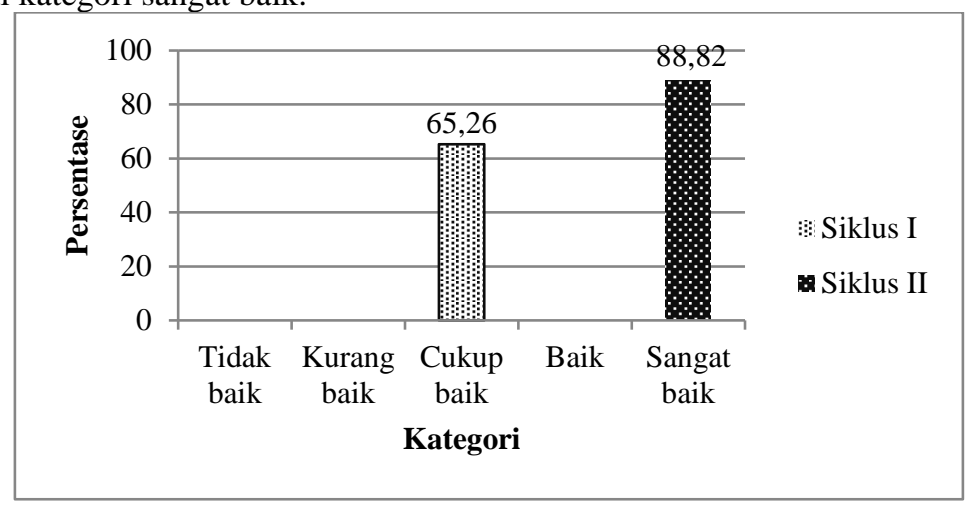

Gambar 3. Hasil observasi sikap siswa

Pada siklus I ssiswa ada yang mendominasi, kurang aktif mencari informasi dan keributan selama pembelajaran mengakibatkan suasana kelas kurang kondusif. Menurut Kunandar (2011) keberhasilan proses belajar dan mengajar apabila terjadinya peningkatan aktivitas siswa ditandai aktif belajar mencari informasi untuk membahas materi pembelajaran sejalan dengan pendapat Suyono \& Hariyanto (2012) proses belajar yang baik akan memperbaiki sikap, keterampilan dan pengetahuan.

Siklus II mengalami peningkatan karena guru memperbaiki cara dalam mengajar. Menurut Hosnan (2014) pembelajaran model IBL yang menekankan pengembangan aspek; pengetauan, siikap, dan keterampilan mengasilkan peningkatan sikap dan keaktivan siswa. Hal ini diperkuat oleh pendapat Purnamasari, Leny \& Saadi (2014) peningkatan sikap meningkat dikarenakan pengaruh perbaikan cara mengajar guru disetiap sintak model IBL yang dikuti peningkatan aktivitas siswa dan guru serta hasil belajar.

\section{Hasil belajar ranah keterampilan}

Penilaian aspek keterampilan dilihat saat siswa melakukan praktikum. Persentase keterampilan terdapat pada Gambar 4 


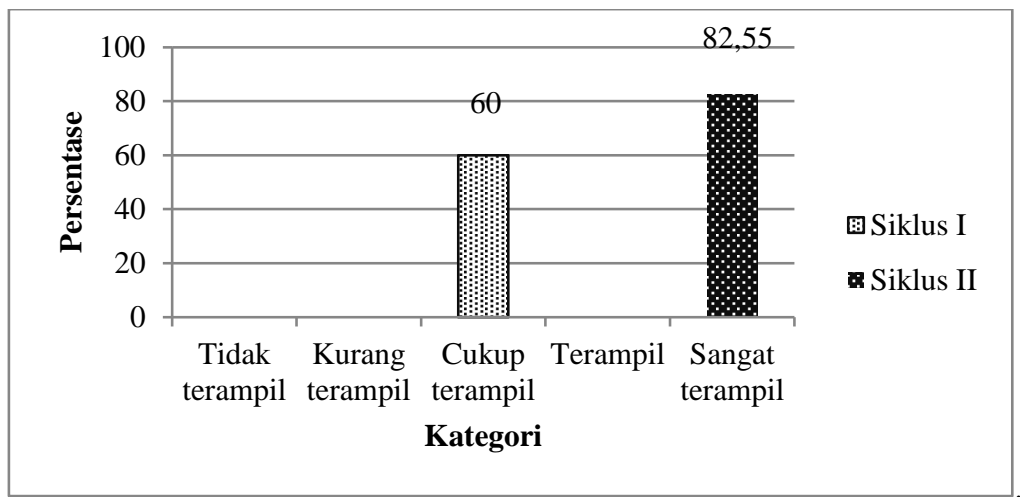

Gambar 4. Hasil observasi keterampilan siswa

Hasil keterampilan siswa meniingkat dari kategori cukup baik menjadi sangat terampil. Siklus I kebanyakan sisw kurang mengetahui cara penggunaan alat percobaan disebabkan kurangnya pengetahuan tentang alat praktikum dan jarang dilakukannya percobaan sehingga keterampilan melaksanakan percobaan kurang terampil. Menurut Jaemjam, Praweenya dan Dachakupt (2015) keterampilan akan meningkat dengan pengalaman belajar dari melihat dan melakukan secara langsung sejalan dengan teori Piaget akan lebih mudah belajar dan mengingat jika menerima pelajaran melalui pengalaman langsung serta memberikan contoh cara penggunaan alat.

Siklus II mengalami peningkatan karena guru melalakukan perbaikan dalam cara mengajar sehingga keterampilan siswa meningkat dan mulai terbiasa menggunakan alat-alat praktikum karena membiasakan melakukan percobaan. Sejalan dengan pendapat Purnamasari, Leny dan Saadi (2014) bahwa hasil belajar keterampilan akan meningkat karena adanya perbaikan guru dalam mengajar seperti menjelaskan secara singkat serta mempraktekkan penggunaan alat.

\section{Self-efficacy}

Menurut Filsaeme (2008) self-efficacy perlu dikembangkan untuk memunculkan keterampilan argumentasi kritis. Hal ini sesuai dengan hasil penelitan Hanifah \& Agustini (2012) model IBL meningkatkan self-eficacy dan keterampilan argumentasi kritis.

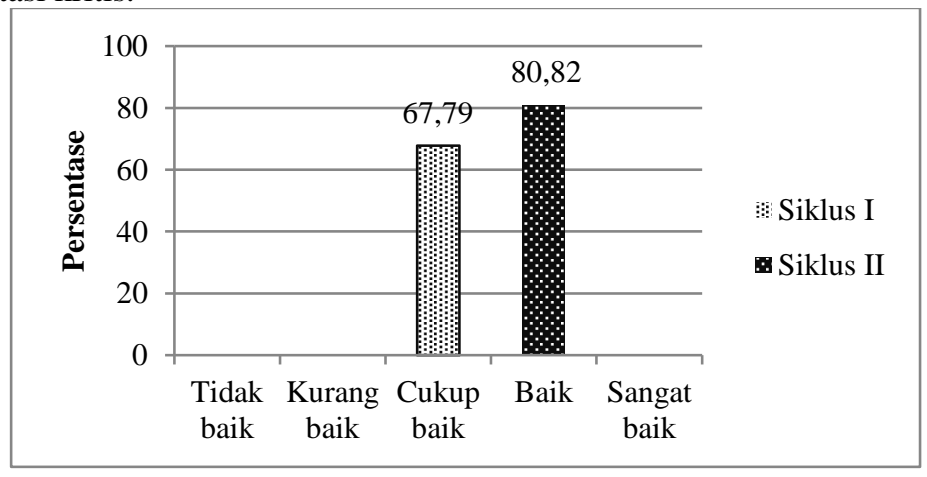

Gambar 5. Perbandingan self-efficacy

Gambar 5 menunjukkan peningkatan dari cukup baik menjadi baik. Menurut Ika, Sumarti, \& Widodo (2017) model IBL memiliki pengaruh postif terhadap self- 
efficacy dan hasil belajar. Model IBL membuat siswa terlibat langsung selama proses pembelajaran seingga kepercayaan dirinya muncul seiring berjalannya waktu. Hal ini diperkuat oleh pernyataan Mundilarto (2013) model IBL menjadikan siswa aktif sehingga pembelajaran efektif untuk meningkatkan self-efficacy diperkuat dengan pendapat Mariana, Haji, \& Saiful (2015) siswa lebih berani dalam menyampaikan argumen (senang berpendat) selama proses pembelajaran. Sejalan dengan pernyataan Maulidah, Rusmansyah, \& Leny (2017) siswa memiliki self-efficacy tinggi ditandai dengan aktif menajwab pertanyaan dari guru.

\section{Keterampilan argumentasi kritis}

Model IBL adalah model pembalajaran yang mudah untuk membangkitkan keterampilan argumentasi kritis disetiap sintaknya. Sejalan dengan hasil peneltian Soraya, Rusmansyah, \& Istyadji (2018) bahwa keterampilan argumentasi kritis meningkat disebabkan dari proses menemukan masalah sampai membuat kesimpulan bersama dan terlatih dalam menyampaikan argumen.

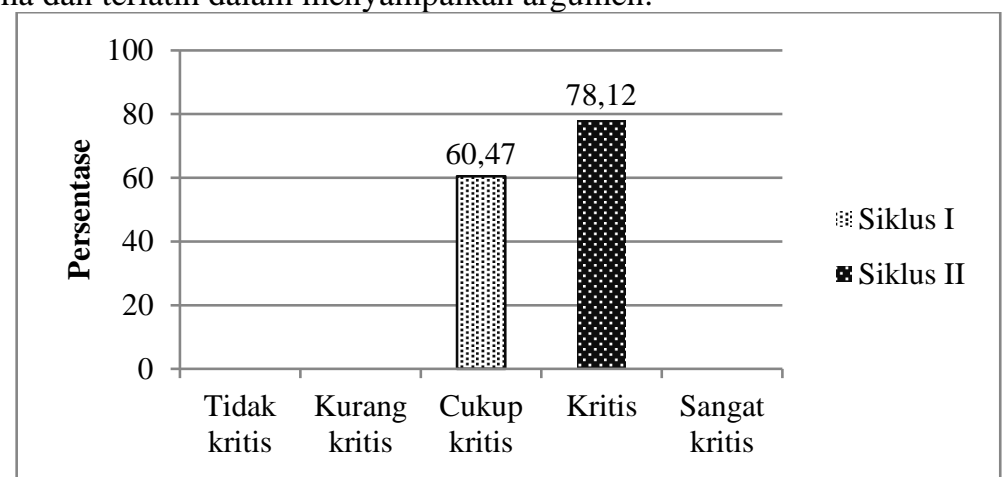

Gambar 6. Perbandingan keterampilan argumentasi kritis

Gambar 6 menunjukkan adanya peningkatan keterampilan argumentasi kritis dari cukup kritis menajdi kritis dengan model IBL. Siklus I sebagian siswa masih belum bisa mandiri sehingga keterampilan argumen masih cukup. Menurut Yustina, Irasyuarna, \& Kusasi (2015) pembelajaran konvensional mengakibatkan ketretrampilan argumentasi siswa cukup rendah, sehingga diperlukan model berpusat pada siswa yaitu IBL. Menurut Aisyah (2015) proses pembelajaran model IBL melatih argumen sehingga keterampilan argumentasi kritis meningkat. Pernyataan ini didukung oleh Stephenson \& Sadier (2016) bahwa model IBL membuat siswa lebih mudah memerikan argumen secara logis dengan menyertakan fakta-fakta yang logsi. Adupun persentasi keterampilan argumentasi kritis setiap indikator dapat dilihat oada Gambar 7. 


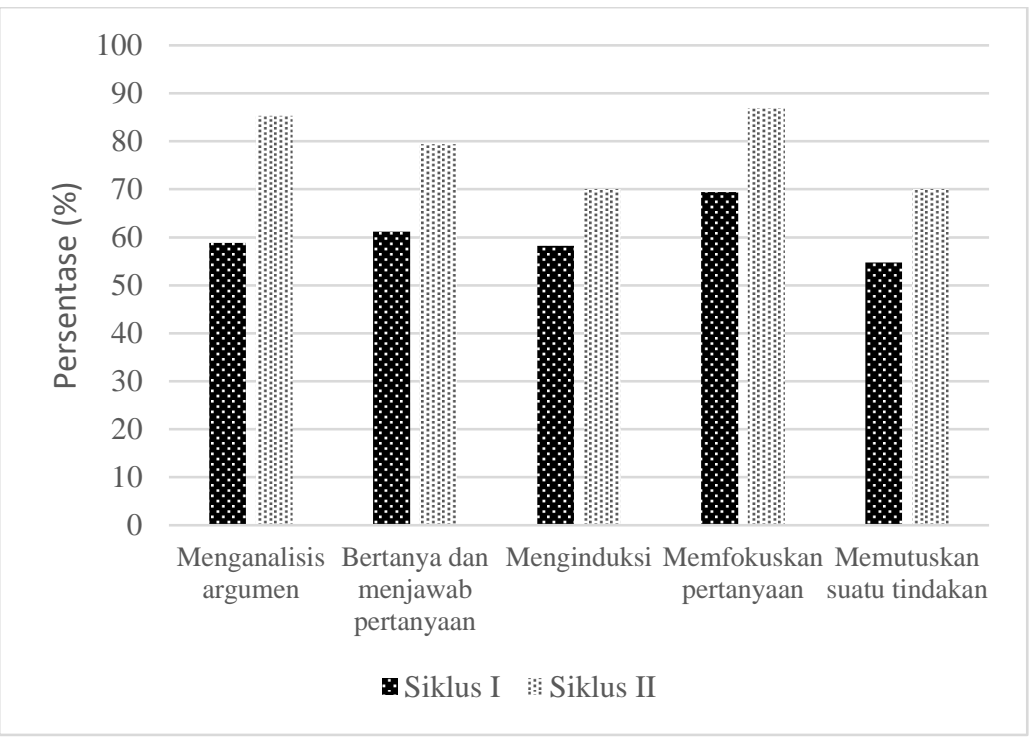

Gambar 7. Hasil tes keterampilan argumentasi kritis

\section{Menganalisis argumen}

Menurut Hanifah \& Agustini (2012) argumentasi siswa meningkat karena pengaruh dari self-efficacy meningkat dimana setiap sintak model IBL menekankan proses argemen dan self-efficacy menggunakan praktikum. Pernyataan tersebut didukung diperkuat hasil penelitan Rusmansyah, Yuanita, Ibrahim, Isnawati \& Prahani (2012) semakin tinggi self-efficacy meningkatkan keterampilan argumentasi kritis.

\section{Bertanya dan menjawab pertanyaan}

Model IBL menjadikan siswaa terbiasa bertanya dan menjawab pertanyaan sehingga terjadi peningkatan menjadi kritis. Sejalan dengan pendapat Prasetyowati \& Suyatno (2016) keterampilan bertanya dan menjawab pertanyaan meningkat karena disetiap sintak model IBL yang menuntut siswa membuat dan menjawab pertanyaan mereka.

\section{Menginduksi}

Keterampilan siswa membuat kesimpulan berdasarkan jawaban sebelumnya meningkat dari cukup kritis menjadi kritis. Hal ini tidak terlepas dari proses pembelajaran model IBL yang berbasis pemecahan masalah. Sejalan dengan hasil penelitian Asranudin \& Rusmansyah (2017) menyatakan model pembelajaran berbasis masalah lebih afektif meningkatkan keterempilan menginduksi.

\section{Memfokuskan pertanyaan}

Keterampilan memfokuskan pertanyaanmeningkat dari kritis menjadi sangat kritisi. Hal ini disebebakan siswa terbiasa memmbuat pertanyaan dari kalimat tidak lengkap, menunjukkan sudah fokus. Sejalan dengan penelitian Asranudin \& Rusmansyah (2017) memberikan bantuan awal dan memberhentikan saat seseorang mulai terampil. 


\section{Menentukan suatu tindakan}

Keterampilan menentukan suatu tindakan meningkat dari cukup kritis menjadikritis. Siklus I siswa belum menguasai serta menemukan alternatif melakukan tindak dikarenakan kurangnya menyelesaikan soal dari guru. Siklus II guru memberikan opsi/pilihan untuk membuat tindakan sebagian besar mereka memahami, menguasai serta mampu mencari alternatif untuk melakukan tindakan yang afektif sejalan pendapat Suryosubroto (2009) guru berperan penting pengelolaan kelas untuk mencapai tujuan yang dirumuskan.

\section{Hasil belajar ranah pengetahuan}

Persentse ketuntasan siswa dalam aspek hasil belajar pengetauan meningkat dapat dililhat pada Gambar 8

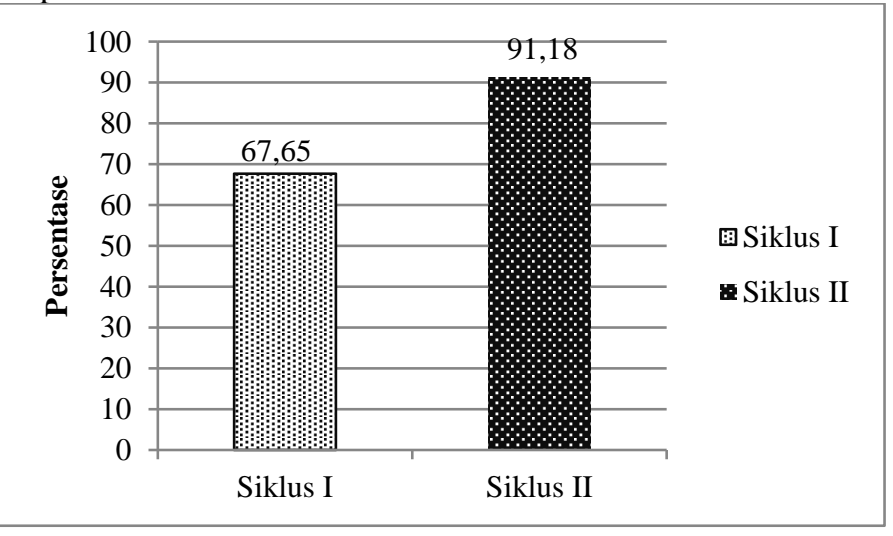

Gambar 8. Hasil penilaian aspek pengetahuan

Ketuntasan siswa siklus I sebesar 67,65 \% berada ditingkat rendah, yang menunjukkan bahwa ketuntasan siswa belum mencapai indikator keberhasilan sebanyak 11 dari 34 orang berada di bawah nilai KBM. Siklus II persentase mengalami peningkatan sebesar 91,18\% hasil tersebut menunjukkan keseluruhan siswa telah memahami yang berarti keseluruhan sisaw ditandai tercapainya KBM. Dampak ini tidak terlepas dari keberasilan guru memperbaiki cara mengajar setiap pertemuan serta membimbing siswa sampai mampu menyelesaikan masalanya sendiri.

Menurut Putri, Irwan dan Dodi (2012) adanya komunikasi dua arah antara pelajar dan pengajar membuat siswa bisa menjawab dan menyelesaikan masalah sendiri. Sesuai degna teori belajar Bruner ketuntasan belajar siswa dipengaruhi oleh aktivitas guru serta hasil penelitian Hendriyarto dan Amrina (2013) ketuntasan belajar dapat ditingkatkan melalui model IBL.

\section{SIMPULAN}

Berdasarkan hasil data penelitian dan pembahasan disimpulkan bahwa model IBL dapat meningkatkan keterampilan argumentasi kritis, self-efficacy dan hasil belajar yang diikuti oleh meningkatnya aktivitas siswa dan keterlaksanaan aktivitas guru. Adapun untuk saran penelitian ini menggunakan indikator keterampilan argumentasi kritis yang berbeda disesuaikan dengan model IBL. 


\section{DAFTAR RUJUKAN}

Aisyah, I. (2015). Penerapan Model Pembelajaran Inkuiri untuk Melatihkan Kemampuan Argumentasi Ilmiah Siswa pada Materi Kalor di SMAN 1 Pacet. Jurnal Inovasi Pendidikan Fisika, 4(2), 83-87.

Ariani, M., Hamid, A., \& Leny. (2015). Meningkatkan Keterampilan Proses Sains dan Hasil Belajar Siswa Pada Materi Koloid dengan Model Inkuiri Terbimbing (Guided Inquiry) pada Siswa Kelas XI IPA 1 SMA Negeri 11 Banjarmasin. Jurnal Inovasi Pendidikan Sains, 6(1), 98-107.

Asranudin, \& Rusmansyah. (2017). Aplication of GI-TPS to Skills Critical Thinking and Self-Efficacy. Journal Of Educational Science and Technology, 1-5.

Danim, S., \& Khairil. (2011). Psikologi Pendidikan (Dalam Perspektif). Bandung: Alfabeta.

Filsaeme, D. K. (2008). Menguak Rahasia Berpikir Kritis dan Kreatif. Jakarta: Erlangga.

Hamalik, N. (2013). Kurikulum dan Pembelajaran. Jakarta: Erlangga.

Hanifah, N., \& Agustini, R. (2012). Peningkatan Self-efficacy dan Berpikir Kritis Melalui Penerapan Model Pembelajaran Inkuiri Materi Pokok Asam Basa Kelas XI SMAN 9 Surabaya. Unesa Journal Of Chemical Education, 1(1), 2733.

Hanifah, N., \& Suhana, C. (2012). Konsep Strategi Pembelajaran. Bandung: Refika Aditama.

Hendiyarto, J., \& Amrina. (2013). Penerapan Model Pembelajaran Inkuiri untuk Melatih Kamampuan Berpikir Tingkat Tinggi Siswa pada Materi Pokok Laju Reaksi. Unesa Journal of Chemical Education, 2(2), 151-158.

Hopkins, D. (2011). Panduan Guru: Penelitian Tindakan Kelas . Yogyakarta: Pustaka.

Hosnan, M. (2014). Pendekatan Saintifik dan Konstektual Dalam Pembelajaran Abad 21 Kunci Sukses Implementasi Kurikulum 2013. Bogor: Ghalia Indonesia.

Ika, J., Sumarti, S. S., \& Widodo, A. T. (2017). Penerapan Model Pembelajaran Inkuiri Terbimbing Terhadap Self-Efficacy dan Hasil Belajar Kimia pada Materi Koloid. Journal Of Innovation Science Education, 6(1), 50-58.

Jaemjam, S., Praweenya, S., \& Dachakupt, P. (2015). Virtual Field Trips With Inquiry Learning and Critical Thinking Process: a Learning Model to Enhance Student Science Learning Outcomes. Procedla-Social and Beavioral Sciences, $1(197), 143-155$.

Kunandar. (2012). Langkah Mudah Penelitian Tindakan Kelas. Jakarta: Rajawali Pers.

Mariana, Y., Haji, A., \& Saiful. (2015). Penerapan Model Pembelajaran Inkuiri Terbimbing Untuk Meningkatkan Keterampilan Berpikir Kritis dan Sikap Sosial Siswa SMA Pada Materi Kelarutan dan Hasil Kali Kelarutan. Jurnal Pendidikan Sains Indonesia, 3(1), 259-270.

Maulidah, A., Rusmansyah, \& Leny. (2017). Meningkatkan Self Efficacy Dan Keterampilan Berpikir Kritis dengan Model Pembelajaran Inkuiri Terbimbing Berbantuan Virtual Laboratory Materi Larutan Penyangga Kelas XI IPA 1 SMA PGRI 4. Journal Of Chemistry And Education, 110.

Mulyasa, H. E. (2015). Guru Dalam Implementasi Kurikulum 2013. Bandung: PT. Remaja Rosdakarya.

Mundilarto. (2013). Keefektifan Pendekatan Inquiry Based Learning Untuk Peningkatan Karakter Siswa SMA pada Pembelajaran Fisika. Cakrawala Pendidikan, 2, 250-257. 
Prasetyowati, E., \& Suyatno. (2016). Peningkatan Penguasaan Konsep dan Keterampilan Berpikir Kritis Siswa Melalui Implementasi Model Pembelajaran Inkuir pada Materi Pokok Larutan Penyangga. Jurnal Kimia dan Pendidikan Kimia (JKPK), 1(1), 67-74.

Purnamasari, R., Leny, \& Saadi, P. (2014). Meningkatkan Hasil Belajar dengan Menggunkan Model Pembelajaran Inkuiri Terbimbing Berbantuan LKS pada Materi Larutan Penyangga Siswa Kelas XI IPA 2 SMA Negeri 12 Banjarmasin. Inovasi Pendidikan Sains, 5, 13-19.

Putri, T. T., Irwan, \& Dodi, V. (2012). Meningkatkan Kemampuan Berpikir Kreatif Siswa dengan Pembelajaran Berbasis Masalah. Jurnal Pendidikan Matematika, 1(1), 49-53.

Rusmansyah, Yuanita, L., Ibrahim, M., Isnawati, \& Prahani, B. K. (2019). Innovative Chemistry Learning Model: Improving The Chritical Thinking Skills And SelfEfficacy Of Pre-Service Cemistry Teachers. Journal of Technology and Science Education, 9(1), 59-76.

Soraya, N., Rusmansyah, \& Istyadji, M. (2018). Pengaruh Model Think Pair Share Problem Solving Terhadap Kemampuan Berpikir Kritis dan Self-Efficacy Siswa. Jurnal Inovasi Pendidikan Sains, 9(1), 70-75.

Stephenson, N. S., \& Sadier, N. P. (2016). Developing Critical Thinking Skills Using The Science Writing euristic in Te Cheminstry Laboratory. Chemistry Education Research and Practice, 17, 72-79.

Sudjana, N. (2014). Penilaian Hasil Proses Belajar Mengajar. Bandung: Remaja Rosdakarya.

Suryosubroto, B. (2009). Proses Belajar Mengajar di Sekolah. Jakarta: Rineka Cipta. Suyono, \& Hariyanto. (2012). Belajar dan Pembelajaran. Bandung: Remaja Rosdakarya.

Trianto. (2011). Mendesain Model-model Pembelajaran Inovatif-Progtesif. Jakarta: Kencana Prenanda Media Group.

Yustina, S., Irhasyuarna, Y., \& Kusasi, M. (2015). Pembelajaran Model Pembelajaran Problem Solving Teradap Kemampuan Berpikir Kritis Siswa Pada Materi Koloid Kelas XI IPA SMA Negeri 4 Banjarmasin. Jurnal Inovasi Pendidikan Sains, 6(2), 22-32. 